\title{
LOCAL INFLUENCER ENDORSEMENTS IMPACT ON CONSUMER PURCHASE INTENTIONS: A REPLICATION STUDY FOR THE INDONESIAN SMES
}

\author{
I Made Harry Kurniawan*) and Hasnul Suhaimi*)
}

*) Department of Management, Faculty of Economics and Business, University of Indonesia Jl. Prof. DR. Sumitro Djojohadikusumo, Kota Depok, Jawa Barat 16424, Indonesia

\begin{abstract}
Several studies have acknowledged that better access to global financial support is one of the SMEs' major challenges. However, only a few of them are suggesting alternative feasible strategies to assist SMEs to gain market share against major firms. A considerable approach by SMEs is to promote their products and brands match with SMEs capacities through local influencer endorsement to stimulate consumer purchase intentions. Indonesian culture suggests Islamic religious moral leader figure as a type of influencer which is believed to have a significant influence on consumers' purchase intention in particular on local social communities. The purpose of this study is to analyze the impact of local influencer endorsements on consumer purchase intentions and the moderating effect of negative publicity on the SME market perspective in Indonesia. A structured questionnaire was created to acquire primary data from 273 respondents using a quantitative research design. The findings from this study indicate that attractiveness, trustworthiness, and familiarity are factors supporting the image of local influencer endorsements, which positively influence consumers' perceptions of quality, purchase intentions, and brand loyalty. This study also shows that negative publicity on local influencer endorsements does not have a moderating effect on consumer purchase intentions.
\end{abstract}

Keywords: SMEs, influencers, endorsers, purchase intentions, perception of quality, brand loyalty, negative publicity

\begin{abstract}
Abstrak: Beberapa studi menyatakan bahwa dukungan sektor keuangan global yang lebih baik merupakan salah satu tantangan utama UKM, namun sedikit dari studi tersebut yang menyarankan suatu strategi alternatif yang layak untuk membantu UKM dalam persaingannya menghadapi perusahaan besar. Pendekatan yang dipercaya tepat bagi UKM adalah dengan mempromosikan produk dan merek mereka sesuai dengan kapasitas UKM melalui dukungan tokoh pemberi pengaruh lokal untuk merangsang niat beli konsumen. Di dalam kebudayaan Indonesia peranan tokoh pemimpin moral agama Islam diyakini mampu memberikan pengaruh signifikan terhadap niat pembelian produkoleh konsumen yang utamanya berada dalam komunitas sosial yang bersifat lokal Penelitian ini bertujuan untuk menganalisa dampak dukungan tokoh lokal terhadap niat beli konsumen dan pengaruh moderasi publisitas negatif pada perspektif pasar UKM di Indonesia. Kuesioner terstruktur telah disusun untuk memperoleh data primer dari 273 responden dengan menggunakan desain penelitian kuantitatif. Hasil penelitian ini menunjukkan bahwa daya tarik, kepercayaan dan keakraban merupakan faktor pembentuk citra atas dukungan dari tokoh lokal pemberi pengaruh, yang secara positif mempengaruhi persepsi konsumen terhadap kualitas, niat membeli dan loyalitas terhadap suatu merek. Penelitian ini juga menunjukkan bahwa publisitas negatif pada tokoh lokal pemberi pengaruh tidak memiliki efek yang cukup moderat terhadap niat beli konsumen.
\end{abstract}

Kata kunci: UKM, influencer, endorser, niat membeli, persepsi kualitas, loyalitas merek, publisitas negatif

${ }^{1}$ Corresponding author:

Email: hkurniawan2012@gmail.com 


\section{INTRODUCTION}

According to a 2018 report from the Ministry of Cooperatives and SMEs of the Republic of Indonesia, the Indonesian SMEs growth has increased to $63,933,617$ units with a labor absorption of $116,673,416$ workers and 298,208.7 billion IDR export income, excluding the income from oil and gas industrial sectors. Although these contributing trends to the country's economy are increasing, the fact that most SMEs' constraints are still related to their access to finance and poor marketing knowledge is rather troublesome (Tahi Hamonangan Tambunan and McKague, 2011). Although SMEs' poor marketing knowledge has been identified as one of SMEs' constraints, it has never been raised as one of the major constraints contributors. Even though, marketing knowledge may lay a foundation that offers important solutions for most SMEs' marketing issues. This argument is supported by the fact that most Indonesian SMEs are still relying only on traditional personal selling methods to promote sales namely door-to-door canvassing techniques and WoM (Word of Mouth) to their existing customers. Another fact also indicates that there are still not enough studies available to suggest alternative marketing strategies for Indonesian SMEs business to compete with major firms.

It is known from previous studies that celebrity endorsements positively affect customers' purchase intentions. Many established corporations commonly use these endorsements as marketing campaign strategies to promote their brands (Osei-Frimpong et al. 2019). McCracken (1989) defines a celebrity endorser as "any individual who enjoys public recognition and who uses this recognition on behalf of a consumer good by appearing with it in an advertisement", where a certain level of recognition and its usage for promotion are emphasized.

In general, SMEs would not be able to compete directly with major established corporations in the context of a celebrity endorsement marketing strategy, whether to gain attention or in funding local celebrities moreover international celebrities. To survive and grow, firms have to strive, earning their market share by knowing how to use marketing mix communication strategies (Keller, 2013), which also true for SMEs business. Thus theoretically, the same concept of celebrity endorsement as a marketing communication strategy should be able to be modified for smaller groups of people, in particular communities that are within the reach of SMEs' business scopes, mainly in regards to promoting their brands' emotional appeal (Solomon, 2017) by using influencer endorsement approach. This study attempts to explore a gap in the previous study of celebrity endorsement effect on purchase intentions by synthesizing the existing research model into a smaller scale to find alternative attainable strategy solutions whereby Indonesian SMEs can gain their larger market share by analyzing the impact of local influencer endorsements on consumer purchase intentions and the moderating effect of negative publicity on the SME market perspective in Indonesia.

\section{METHODS}

A survey was conducted to collect the primary data needed. The survey comprised a structured questionnaire that was given to members of the Indonesian general public who were willing to participate as respondents. Several concerns regarding the exact number of total population existed, time and budget constraints to conduct the research are mainly the reasons behind the chosen method applied for this study. This research employed a single cross-sectional design approach, using Google forms electronic survey methods and a nonprobability convenience sampling technique. Before the main study, pre-test data from the first 30 respondents were collected to test the instrument used for this research (Malhotra et al. 2017).

The survey managed to collect 273 valid respondents with the demographic respondents' profile as presented in Table 1. The survey result was gathered in Jakarta, Indonesia. The survey was conducted within 33 days, from 22 February 2020 to 26 March 2020, using the electronic interviewing method through an internet network with the assistance of a google form application. The survey invitation was conducted via WhatsApp application blast which provides a direct link for the participants around the Indonesian region to a set of constructed questionnaires for them to enter their inputs.

The scales used to measure the constructs, as shown in Figure 1, were taken from an earlier study (OseiFrimpong et al. 2019). All of the scales were measured on a five-point Likert scale ranging from 1 (strongly disagree) to 5 (strongly agree), apart from attractiveness, trustworthiness, and familiarity, which were measured on a seven-point semantic differential 
scale. Influencer Endorsement (IE) was constructed as second order, which was measured using attractiveness, trustworthiness, and familiarity. Attractiveness (ATTR) and trustworthiness (TRUS) were measured on a sevenpoint semantic differential scale with a five-item scale (Ohanian, 1990). Familiarity (FAMI) was measured on a seven-point semantic differential scale with a threeitem scale (Spry et al. 2011).

Table 1. Demographic profile of the respondents

\begin{tabular}{lcc}
\hline Profile & Amount & Percentage (\%) \\
\hline Gender & 135 & 49.45 \\
Male & 138 & 50.55 \\
Female & & \\
Age (in Years) & 13 & 4.76 \\
$<18$ & 233 & 85.35 \\
$18-34$ & 27 & 9.89 \\
$35-55$ & 0 & 0.00 \\
$56-74$ & 0 & 0.00 \\
$>74$ & & \\
Educational Level & 5 & 1.83 \\
$<$ Junior High & & \\
School & 121 & 44.32 \\
High School & & \\
\hline
\end{tabular}

The consumer perception of quality (CPQ) was measured on a four-item scale (Spry et al. 2011). Consumer Purchase Intention (CPI) was measured on a six-item scale (Liu and Brock, 2011). Consumer Brand Loyalty (CBL) was measured on a three-item scale (Yoo and Donthu, 2001). Negative Publicity (NP) was measured on a three-item scale (Money et al. 2006), which was related to subjects considered taboo in Indonesian culture, namely drug abuse and sex scandals. All of these measures with each of their factor loadings are presented in Table 2.

\begin{tabular}{lcc}
\hline Profile & Amount & Percentage (\%) \\
\hline Diploma & 9 & 3.30 \\
Bachelor Degree & 128 & 46.89 \\
Master Degree & 9 & 3.30 \\
$>$ Master Degree & 1 & 0.37 \\
Mean Monthly Income (in Million IDR) & \\
$<=3,5$ & 121 & 44.32 \\
$3,5-5$ & 65 & 23.81 \\
$5-7,5$ & 46 & 16.85 \\
$7,5-10$ & 22 & 8.06 \\
$10-15$ & 13 & 4.76 \\
$15-20$ & 2 & 0.73 \\
$>=20$ & 4 & 1.47 \\
\hline
\end{tabular}

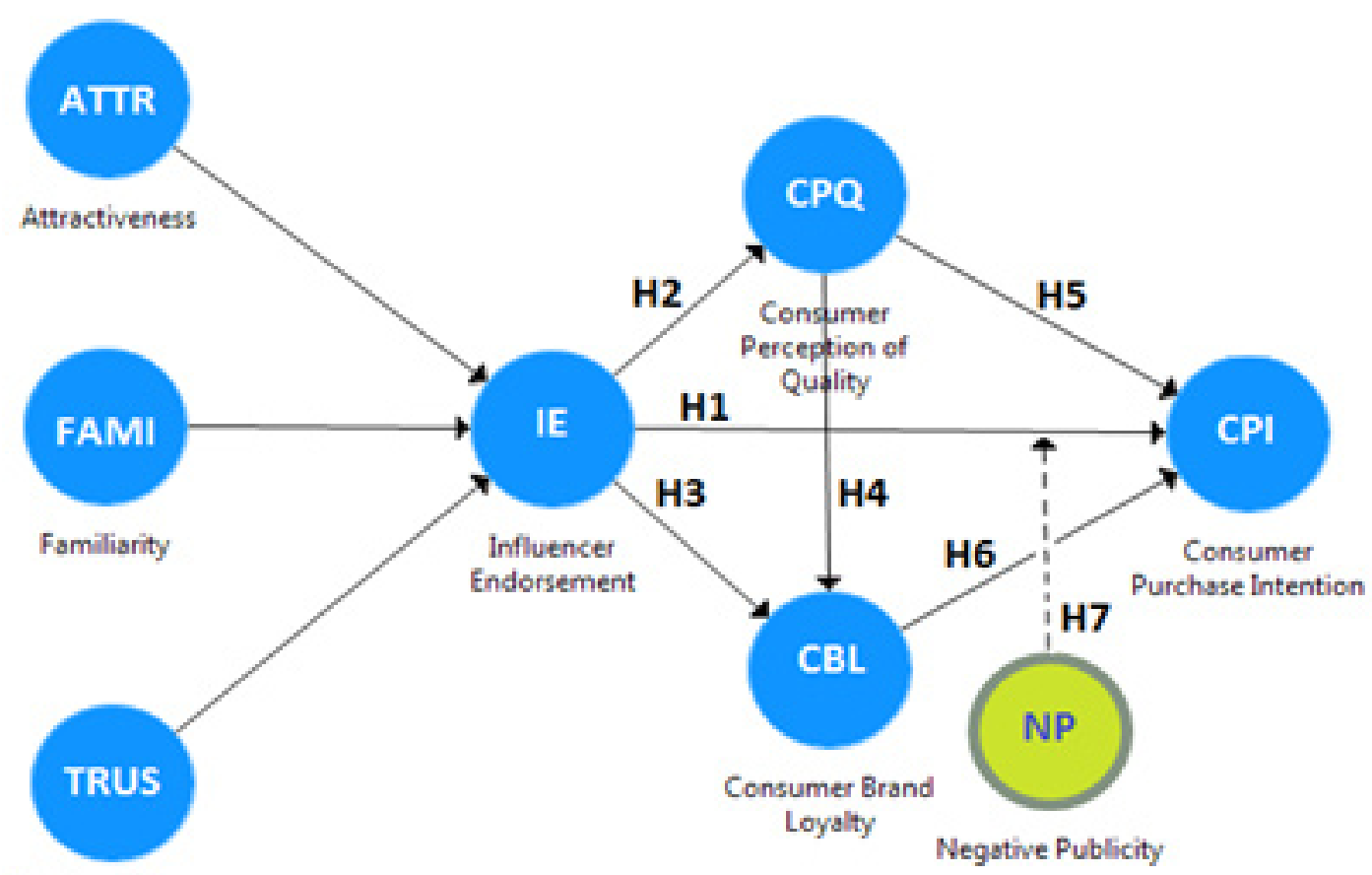

Trustworthiness

Figure. 1. Hypothesized model 
Table 2. Measures and factor loadings

\begin{tabular}{|c|c|c|c|c|c|}
\hline Item & FL & $\mathrm{CR}$ & Item & FL & CR \\
\hline Attractiveness (ATTR) & & 0.883 & Consumer Perception of Quality (CPQ) & & 0.910 \\
\hline Attractive - Unattractive & 0.812 & & $\begin{array}{l}\text { Brand endorsed by influencers are of very } \\
\text { high quality }\end{array}$ & 0.825 & \\
\hline Classy - Not classy & 0.815 & & $\begin{array}{l}\text { Brand endorsed by influencers are of very } \\
\text { consistent in quality }\end{array}$ & 0.839 & \\
\hline Handsome / Beautiful - Ugly & 0.750 & & $\begin{array}{l}\text { Brand endorsed by influencers offer } \\
\text { excellent features }\end{array}$ & 0.843 & \\
\hline Elegant - Plain & 0.717 & & $\begin{array}{l}\text { Brands endorsed by influencers are very } \\
\text { reliable }\end{array}$ & 0.877 & \\
\hline $\begin{array}{l}\text { Manly / Feminine - Not manly / Not } \\
\text { feminine }\end{array}$ & 0.781 & & Consumer Brand Loyalty (CBL) & & 0.389 \\
\hline Trustworthiness (TRUS) & & 0.930 & $\begin{array}{l}\text { I feel loyal to brands endorsed by my } \\
\text { favourite influencer }\end{array}$ & 0.793 & \\
\hline Dependable - Undependable & 0.848 & & $\begin{array}{l}\text { It is likely that brands endorsed by my } \\
\text { favourite influencer will be my first } \\
\text { choice }\end{array}$ & 0.811 & \\
\hline Honest - Dishonest & 0.867 & & $\begin{array}{l}\text { I will not buy any other brands if a brand } \\
\text { endorsed by my favourite influencer is } \\
\text { available }\end{array}$ & 0.787 & \\
\hline Reliable - Unreliable & 0.817 & & Consumer Purchase Intention (CPI) & & 0.867 \\
\hline Sincere - Insincere & 0.879 & & $\begin{array}{l}\text { Brands endorsed by influencers draw my } \\
\text { attention easily }\end{array}$ & 0.693 & \\
\hline Trustworthy - Untrustworthy & 0.850 & & $\begin{array}{l}\text { Brands endorsed by influencers easily } \\
\text { come to mind whenever I have to make a } \\
\text { purchase }\end{array}$ & 0.672 & \\
\hline Familiarity (FAMI) & & 0.891 & $\begin{array}{l}\text { If my favourite influencer endorsed a } \\
\text { brand, I will buy it no matter what }\end{array}$ & 0.734 & \\
\hline Not familiar - Very familiar & 0.781 & & $\begin{array}{l}\text { I buy a brand because I like the influencer } \\
\text { endorsing it }\end{array}$ & 0.782 & \\
\hline Do not recognize - Do recognize & 0.895 & & $\begin{array}{l}\text { I will consider buying a product endorsed } \\
\text { by my favourite influencer }\end{array}$ & 0.727 & \\
\hline \multirow[t]{5}{*}{$\begin{array}{l}\text { Have not heard of before - Have } \\
\text { heard of before }\end{array}$} & 0.866 & & $\begin{array}{l}\text { I am happy to buy a brand endorsed by } \\
\text { my favourite influencer }\end{array}$ & 0.717 & \\
\hline & & & Negative Publicity (NL) & & 0.946 \\
\hline & & & $\begin{array}{l}\text { Influencers who fall into negative } \\
\text { publicity are not credible }\end{array}$ & 0.918 & \\
\hline & & & $\begin{array}{l}\text { Influencers who fall into negative } \\
\text { publicity are not dependable }\end{array}$ & 0.924 & \\
\hline & & & $\begin{array}{l}\text { Influencers who fall into negative } \\
\text { publicity are not reliable }\end{array}$ & 0.929 & \\
\hline
\end{tabular}

The Indonesian Culture and SMEs on Islamic Branding

A Hofstede dimensional approach study about Indonesian culture showed that, compared to other Asian countries, Indonesians can be classified as having a significant power distance, a collectivist outlook, a short-term orientation, weak uncertainty avoidance, and a feminist culture (Irawanto, 2009). Indonesians uphold collectivist values, which leads to social group relationships being based on morals and family values that resonate with their higher appreciation for leaders in social group interactions, which is defined by Hofstede's as significant power distance (Hofstede, 2005) in Indonesian culture. Gani (2004) in his study stated that Indonesian leadership characteristics can be considered as having a paternalistic leadership style where influential leaders play the role of a father with its attributes of wisdom and honesty. Marschall (1996) acknowledges two topological leaders in Indonesia; 
one comprises official-design leaders (i.e. tokoh desa, pamong desa), where their personal qualities are less important, and the other comprises moral leaders (i.e. ulama, imam).

Borgen (2011) defines the main challenge in the world commodity market as still being product differentiation. Previous studies have shown that the most successful commodity products are affected by consumers' perceptions of brand differentiation (Buchholz and Wördemann, 2001). With a population of more than $88 \%$ Muslims out of 263 million Indonesians (Kettani, 2010), the Islamic branding market for Indonesian SMEs could be described as a sizeable potential market and source of product differentiation. Islamic branding may as well serve as an entry barrier strategy for SMEs against established global corporations, as global corporations have to make intelligent consideration on how much they should focus on any particular markets which may not directly be aligned to their existing global strategy (Wilson and Liu, 2011)

\section{Celebrity and Influencer Endorsement}

A study to identify how effective celebrity endorsement and influencer endorsement has indicated that compared to traditional celebrity endorsers where they gain public recognition through their professional talent, influencer endorsers gain their acknowledgment by branding themselves as experts on social media platforms (Schouten et al. 2019). This previous study was performed using the same dimensions and variables to compare the effectiveness of celebrity endorsement and influencer endorsement. Thus using this logic, it is safe to assume that the same dimensions and variables that are applied to performing a study on the celebrity endorsement effect on purchase intentions can also be used to performing a study on the influencer endorsement effect on purchase intentions.

Influencers terminology discussed in marketing communication strategies commonly refers to social media influencers, even though the term itself should not be exclusively used only to describe a particular form of media to be used for communication, a digital social media form in this matter. A broader definition of influencer can be found by understanding the behavior of individuals in certain communities through Social Identity Theory (SIT), consumer behavior, and social influencer approach.
Social Identity Theory, Consumer Behavior, and Social Influencers

Social Identity Theory (SIT) defines an individual's understanding that he/she belongs as a member of certain social groups that share emotional and value significance (Tajfel, 1972). Consumer behavior theory proves that social identity has a significant impact on consumer attitudes and beliefs which affect consumers' selections and their decisions to purchase particular products (Solomon, 2017). Social influence can be seen as how an individual who plays a role in a particular social group attempts to assimilate the group's characteristics, which is then often demonstrated in that individual's purchasing behavior towards certain products to attain his/her position in the social group (O'Shaughnessy and O'Shaughnessy, 2002). In any particular social group, one or several individuals are more able to influence the other members of the group; they contribute to shaping the characteristics of the social group and are known as group leaders (Stogdill, 1948). Social influencers are not necessarily those who claim to be leaders in a social group (Stanforth, 1995) but are individuals who are perceived by the other members to have leadership characteristics, to have a high degree of involvement with their social identity, and whose advice is sought for making decisions (Kang and Park-Poaps, 2010). These studies argue that influencer terminology is not exclusively attached to digital social media platforms only, but is also relevant to the more traditional context of social groups.

\section{Model Development and Hypotheses}

The characteristics of communicator agents in terms of source credibility are believed to have a significant effect on the persuasiveness of the messages in marketing communication strategies, including messages that significantly affect consumer purchasing intentions (Lafferty et al. 2015). Therefore, the selection of a spokesperson who has a combination of attractiveness, trustworthiness, and expertise in communicating products or brands to consumers is considered to be crucial (Ohanian, 1990). In a related study, perceived endorser familiarity is also considered to be an important factor in conveying successful messages to consumers, where the members of smaller social groups are more likely to be more familiar and close to each other (Spry et al. 2011). The practitioner approach performed in a previous study claimed that the endorsement communication strategy's greatest impact 
can be achieved by aligning conveyed messages with the endorsers' characteristics. This study also stated that expert endorser is only one of many endorser types that are used to convey persuasive messages to targeted audiences (Erdogan and Baker, 2015). Therefore, in the context of the Indonesian SME market, which is mostly related to FMCG commodity products, there is no urgent requirement for a particular expert type of endorsers needed. Therefore, it could be stated that the variables used to construct influencers' endorsement characteristics are mainly based on influencers' attractiveness, trustworthiness, and familiarity.

H1: Influencer endorsement as perceived in endorsers' attractiveness, trustworthiness, and familiarity has a positive influence on consumers' purchase intentions.

Several articles (Martensen et al. 2018) (Belch and Belch, 2018) on marketing suggest that influencers with both constructed models of source credibility model (expertise and trustworthiness) (Ohanian, 1990) and source attractiveness model (likeability, similarity, and familiarity) (McGuire, 1985) are more likely to have a significant influence among their followers in establishing a perception of quality for brands or products.

H2: Influencer endorsement has a positive influence on consumers' perception of the quality of an endorsed brand.

A study on customer behavior claimed that influencers with the attributes of attractiveness, trustworthiness, and familiarity are likely to be more successful at promoting brand loyalty, as their influence is more conditionally accepted by their followers. These influencer's attributes lead their followers to a higher degree of attention and recall, more awareness, a certain positive belief, and attitude towards particular brands or products (Solomon, 2017).

H3: Influencer endorsement has a positive influence on consumers' brand loyalty

Consumers' perceptions of quality that come from their expectations of products or brands will turn into satisfaction when their expectations are met (Olsen, 2002). The higher their expectations, the greater their satisfaction, and the perceived quality they experience when their expectations have been fulfilled which will lead to long-term customer brand loyalty (Juran and Godfrey, 1999).

H4: Consumers' perceptions of a brand's quality have a positive influence on their brand loyalty.

A previous study stated that brand attitude and brand image interrelate with each other and both act as variables on constructing brand equity and forming brand preferences, which positively affect consumers' purchasing intentions (Chang and Liu, 2009). A similar study by Garretson and Clow (1999) also showed that consumers' perceptions of quality have a positive effect on their purchase intentions.

H5: Consumers' perceptions of the quality of a brand have a positive influence on their purchase intentions

Kamins and Marks (1991) argued that the more consumers are exposed to brands, the more they become familiar and the more consumers' loyalty can be expected towards particular brands. This is then translated further into brand preference, which finally leads to consumers' purchase intentions for specific brands.

H6: Consumers' loyalty towards a brand has a positive influence on their purchase intentions.

\section{The Moderating Effect of Negative Publicity}

Although previous studies have shown some evidence of success regarding the use of influencer endorsement in marketing strategy communication, negative publicity from influencers has also been proven to have a significant negative effect on influencers' attractiveness and credibility (Belch and Belch, 2018). The more effective influencers are, the more damage is caused by the impact of any negative publicity. This is because influencers' effectiveness towards brands is mostly achieved by their bringing their image and meaning to the products and brands they are endorsing (McCracken, 1989).

H7: Negative publicity from endorsers weakens the effects of the endorsement's influence on consumers' purchase intentions. 


\section{RESULTS}

\section{Data Analysis}

All of the scales recorded a Cronbach alpha of $\alpha>0,7$ with a correlation significance of $\rho<0.05$. The PLSSEM method with SmartPLS software (v.3.2.3) was used to compute the available data. All of the variables measuring the second-order construct (Influencer Endorsement - IE) were treated as formative measures, as shown in Figure 1. A bootstrapping procedure of 1000 subsamples was performed with a significance level using a two-tailed distribution. The indicator outer weights of the formative construct are presented in Table 3 with their levels of significance. All of the indicators show their significance with $\rho<0,05$, which suggests their relative importance to the model construct (Hair et al. 2012). Table 2 shows all of the factor loadings and Composite Reliability (CR) show values above 0,6 , which indicates that the items were aligned onto the constructs they were intended to measure.

\section{PLS Structural Model Result}

A detailed list of the path coefficients with their respective t-values, R2 (coefficient of determinant), Q2 (cross-validated redundancy), and f2 (effect size) are presented in Table 4. R2 measures the accuracy of the model's prediction, Q2 measures the inner-models predictive accuracy, and $\mathrm{f} 2$ calculates each path model effect and measures the spectrum level of the predictor latent variable whether it has a weak, medium, or strong effect at a structural level.

Table 4 shows that all six hypotheses are supported by the research output. Hypothesis H1 $(\mathrm{M}=0.388 ; \rho<$ $0.05 ; \mathrm{R} 2=0.458)$ suggests that influencer endorsements do indeed consider the level of attractiveness, trustworthiness and familiarity on its construct, and shows that consumers' perceptions of quality and brand loyalty have a positive effect on their purchasing intentions. Hypothesis $\mathrm{H} 2(\mathrm{M}=0.316 ; \rho<0.05 ; \mathrm{R} 2=$ 0.098) suggests that influencer endorsements have a positive effect on forming consumers' perceptions of quality towards brands, which in turn leads to brand loyalty and purchasing intentions. Hypothesis $\mathrm{H} 3(\mathrm{M}=$ $0.368 ; \rho<0.05 ; R 2=0.204$ ) suggests that brand loyalty takes into account the positive effect of influencer endorsements and consumers' perceptions of quality, which lead to purchasing intentions. Sequentially, hypotheses H4 $(\mathrm{M}=0.278 ; \rho<0.05 ; \mathrm{R} 2=0.204), \mathrm{H} 5$ $(\mathrm{M}=0.438 ; \rho<0.05 ; \mathrm{R} 2=0.458)$ and H6 $(\mathrm{M}=0.379$; $\rho<0.05$; R2 $=0.458$ ) imply that the positive effect of consumers' perceptions of quality contributes directly to both brand loyalty and purchasing intentions, and contributes indirectly to purchasing intentions through brand loyalty.

Table 3. Weight of indicators and their significance

\begin{tabular}{|c|c|c|c|c|c|}
\hline & $\mathrm{O}$ & M & STDEV & T-Stats & P Values \\
\hline $\mathrm{AT} 1 \rightarrow \mathrm{ATTR}$ & 0.812 & 0.811 & 0.029 & 28.418 & 0.000 \\
\hline $\mathrm{AT} 1 \rightarrow \mathrm{ATTR}$ & 0.815 & 0.815 & 0.028 & 29.483 & 0.000 \\
\hline $\mathrm{AT} 3 \rightarrow \mathrm{ATTR}$ & 0.750 & 0.747 & 0.033 & 22.458 & 0.000 \\
\hline $\mathrm{AT} 4 \rightarrow \mathrm{ATTR}$ & 0.717 & 0.714 & 0.046 & 15.538 & 0.000 \\
\hline $\mathrm{AT} 5 \rightarrow \mathrm{ATTR}$ & 0.781 & 0.782 & 0.026 & 30.465 & 0.000 \\
\hline FA $1 \rightarrow$ FAMI & 0.781 & 0.779 & 0.029 & 27.237 & 0.000 \\
\hline $\mathrm{FA} 2 \rightarrow \mathrm{FAMI}$ & 0.895 & 0.896 & 0.012 & 73.379 & 0.000 \\
\hline FA3 $\rightarrow$ FAMI & 0.886 & 0.886 & 0.014 & 64.542 & 0.000 \\
\hline $\mathrm{TR} 1 \rightarrow \mathrm{TRUST}$ & 0.848 & 0.846 & 0.023 & 37.384 & 0.000 \\
\hline $\mathrm{TR} 2 \rightarrow \mathrm{TRUST}$ & 0.867 & 0.866 & 0.021 & 42.258 & 0.000 \\
\hline $\mathrm{TR} 3 \rightarrow \mathrm{TRUST}$ & 0.817 & 0.816 & 0.025 & 33.235 & 0.000 \\
\hline $\mathrm{TR} 4 \longrightarrow \mathrm{TRUST}$ & 0.879 & 0.878 & 0.017 & 50.341 & 0.000 \\
\hline TR5 $\rightarrow$ TRUST & 0.850 & 0.849 & 0.021 & 40.921 & 0.000 \\
\hline $\mathrm{IE} \rightarrow \mathrm{ATTR}$ & 0.410 & 0.410 & 0.018 & 22.764 & 0.000 \\
\hline $\mathrm{IE} \rightarrow \mathrm{FAMI}$ & 0.271 & 0.271 & 0.015 & 18.014 & 0.000 \\
\hline $\mathrm{IE} \rightarrow$ TRUS & 0.458 & 0.458 & 0.019 & 23.762 & 0.000 \\
\hline
\end{tabular}

Note: ATTR-Attractiveness; FAMI-Familiarity; TRUST-Trustworthiness; IE-Influencer Endorsement.

O-Original Sample; M-Mean Sample; STDEV-Standard Deviation; T Statistics - (|O/STDEV|) 
Table 4. Path estimates for proposed model

\begin{tabular}{ccccccccc}
\hline PATH & $\begin{array}{c}\text { Original } \\
\text { Sample }(\mathrm{O})\end{array}$ & $\begin{array}{c}\text { Sample } \\
\text { Mean }(\mathrm{M})\end{array}$ & $\begin{array}{c}\text { Standard Deviation } \\
(\text { STDEV })\end{array}$ & $\begin{array}{c}\text { T Statistics } \\
(|\mathrm{O} / \mathrm{STDEV}|)\end{array}$ & P Values & $\mathrm{R}^{2}$ & $\mathrm{Q}^{2}$ & $\mathrm{f}^{2}$ \\
\hline $\mathrm{H} 1$ & 0.385 & 0.388 & 0.057 & 6.813 & 0.000 & 0.458 & 0.216 & 0.030 \\
$\mathrm{H} 2$ & 0.313 & 0.316 & 0.056 & 5.638 & 0.000 & 0.098 & 0.062 & 0.109 \\
$\mathrm{H} 3$ & 0.368 & 0.368 & 0.061 & 6.048 & 0.000 & 0.204 & 0.116 & 0.090 \\
$\mathrm{H} 4$ & 0.275 & 0.278 & 0.054 & 5.138 & 0.000 & & & 0.086 \\
$\mathrm{H} 5$ & 0.436 & 0.438 & 0.053 & 8.145 & 0.000 & & & 0.167 \\
$\mathrm{H} 6$ & 0.380 & 0.379 & 0.058 & 6.547 & 0.000 & & & 0.210 \\
$\mathrm{H} 7$ & -0.055 & -0.059 & 0.042 & 1.294 & 0.196 & & & 0.005 \\
\hline
\end{tabular}

The previous study performed in Ghana (Osei-Frimpong et al. 2019) was considered to be appropriate for the adaptation of a similar study in Indonesia, as both Ghana and Indonesia are in the same country category and level of emerging developing markets with several similarities in the consumer behavior aspects. The result of this replication research conducted in Indonesia for local influencer endorsers shows a similar interconnections output pattern as it was with its initial research performed in Ghana applied for celebrity endorsers.

This research conceptualization suggests that consumers' perceptions of quality and consumers' brand loyalty are both important in their relationships supporting the influencer endorsement's positive impact on consumers' purchasing intentions. Although they significantly support the proposed research model, the variables show just a moderate interrelationship caused by dispersing respondent responses, which raises a possible indication of unequal appreciation of public trust towards types of Indonesian influencer leaders (i.e. official-design leaders and spiritual-moral leaders) that should be covered in further studies. The focused response from participants towards consumers' perception of a quality variable more likely would strengthen the interconnection value of consumers' brand loyalty variable which then leads to higher interconnection value to consumers' purchase intentions. Since the questioners structured as per initial research without identifying the local influencer endorser in particular as official-design leaders or spiritual-moral leaders, disperse participants' respond are expected between the two types of Indonesian leaders. Nevertheless, the result of this study remains supporting the concept that significant local figures indeed provide a positive influence on brands being endorsed which then likely to affect the consumers' perceptions of brand quality.

\section{The Interaction Effect}

Table 4 implies that hypothesis H7 ( $\mathrm{M}=-0.059 ; \rho=$ $0.169 ;$ t-value $=1.294 ; \mathrm{f} 2=0.005)$, negative publicity as a moderating variable of influencer endorsement towards purchasing intentions was not supported and has a nonsignificant effect as the correlation significance value did not meet the requirements of $\rho<0,05$ and a t-value of $>$ 1.96. Figure 2 shows the path effect between Influencer Endorsement (IE) and Purchasing Intentions (PI) and how the moderating effect of Negative Publicity (NP at $-1 \mathrm{SD}$ and NP at $+1 \mathrm{SD}$ ) was not met while conducting this research.

Negative publicity in theory suggests the weakening effect of an influencer endorsement's impact on consumers' purchasing intentions (McCracken, 1989). However, this current study provides evidence that the negative publicity moderating variable by itself could not decisively determine the effect of influencer endorsement on consumer purchase intentions without taking into account the components constructing the influencer endorsement variable. The more significance that exists between the interconnection from the components constructing the influencer endorsement more likely would reduce the significance of the effect from negative publicity moderating variable and vice versa. The implication above correlates with the existing study regarding Social Identity Theory (SIT), consumer behavior, and social influencers which argue that the stronger bonds and influence from a significant figure is relatively stronger in smaller social communities compares to larger ones.

Contrary to a previous study by (McCracken, 1989), this study shows that although there is a trend indicating the potential for a weakening effect to occur, as shown in Figure 2, the result remains to show that there is not enough evidence to conclude the weakening effect 
exists in this study. This phenomenon can be explained with the assistance of the selective distortion concept by (Kotler and Keller, 2016), which argues that some people tend to interpret information in a way that supports concepts already structured in their mind in which they believe to be true.

\section{Managerial Implications}

This study has established the importance of influencer endorsement as an alternative marketing approach for SMEs in emerging developing countries such as Indonesia by using influencer figures in social groups. SME managers are expected to selectively match the characteristics of the influencers they use to endorse their brands. SMEs that choose to endorse Islamic brands are encouraged to approach a type of Indonesian moral leaders who are associated with Islamic religious leaders in their local societies. Furthermore, these Islamic moral and religious leaders may act as a bridge to other Islamic organization networks, namely madrasahs, Islamic boarding schools, Islamic political parties, and other Islamic religious networks.

It is also acknowledged that the deeper the influence of figures is planted on consumers' minds, the higher the effect of influencer endorsement on those consumers. At the same time, the more it becomes less sensitive to the negative publicity that may arise towards the influencer figures. A strong bond of connection among people relatively can be established in a smaller group of society; therefore the wise approach for managers is to study and target the society influencer figures which match with the SMEs products and brands to be endorsed. Furthermore, although the approach suggested is not limited to Islamic moral and spiritual influencer leaders only, it is now becoming clearer that this type of influencer figure is currently to be considered as the most suitable marketing influencer endorsement to SME products and brands for the Indonesian market.

Based on the arguments proposed above, SME managers should not hesitate to perform this alternative strategy approach on using local influencer endorsement to promote their products and brands moreover for this strategy to be copied by established major firms. Many major firms most likely already have their target consumers with more general characteristics where the firms' marketing strategy is based upon it. Furthermore, this approach is considered to be appropriate for SME practitioners, as the local influencer endorsement strategy would likely more efficient when it is built from a smaller local social community that is more immune to negative publicity and providing more bonds to its consumers before stepping into the next larger market.

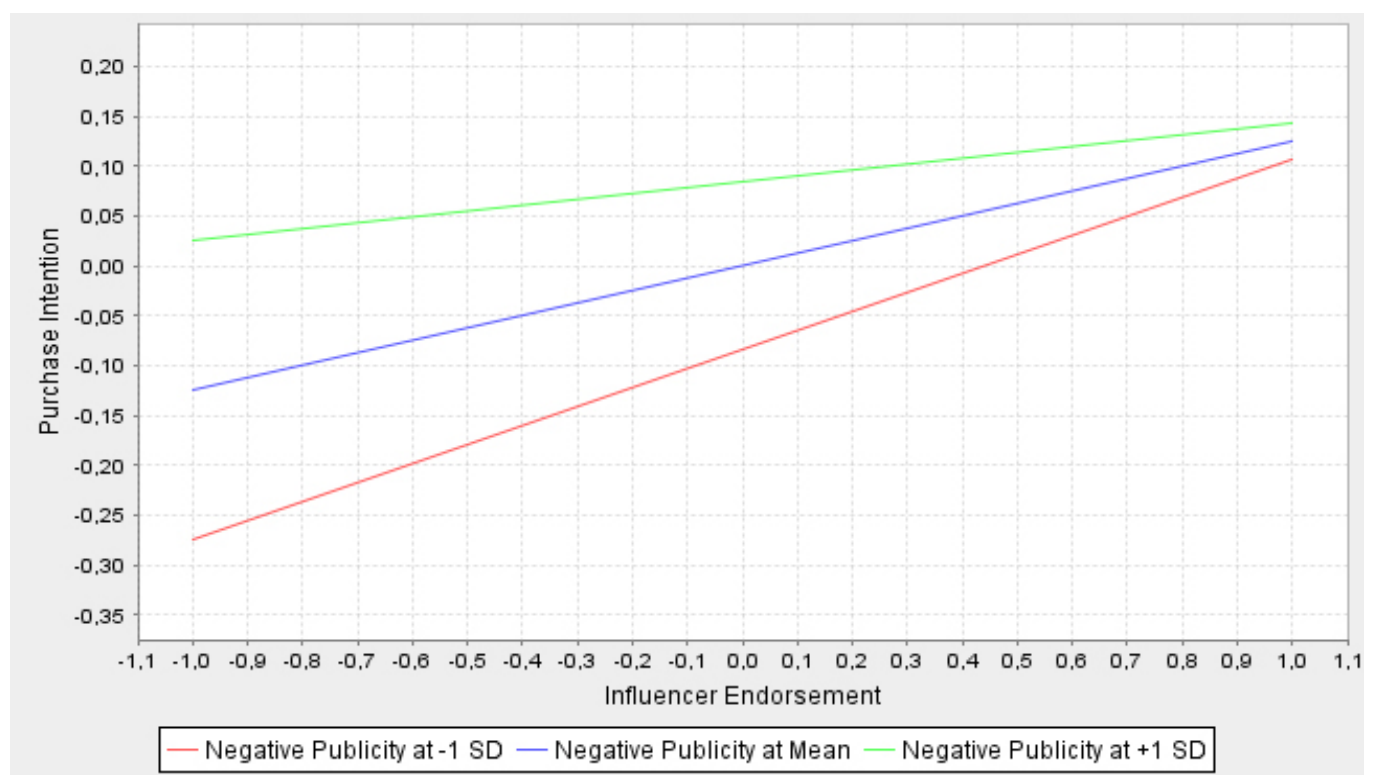

Figure 2. Moderation effect of negative publicity on purchase intention 


\section{CONCLUSIONS AND RECOMMENDATIONS}

\section{Conclusions}

This current replication research has shown similar output patterns of a smaller scale constructed from the initial research of celebrity endorsement which was reduced into local influencer endorsement with the same proposed hypotheses modeling, including its moderating negative publicity variable. It shows that local influencer endorsement has a positive significant effect on consumers' purchase intention with the support of other variables within the constructed hypothesis model, introducing them as consumers' perception of quality and consumers' brand loyalty. Negative publicity moderation introduced in this research has no significant effect on consumers' purchase intention since its expected significant effect is highly reduced by the main attributes constructing the image of influencer endorsement (attractiveness, trustworthiness, and familiarity) in which correlate to the selective distortion concept. This current replication research has proven that an alternative marketing strategy of using influencer endorsement on a local scale for the Indonesian SMEs is a valid approach for the practitioners to gain more of Indonesian market share in competition with major established firms.

\section{Recommendations}

This study's survey was designed as single and crosssectional, which means that the samples were only taken once. An experimental design could be implemented for future studies to evaluate the congruence conclusion claimed in this study, to examine results gained from different Indonesian leadership types. Finally, future studies could evaluate the effectiveness of the influencer endorsement marketing model for SMEs by studying its impact on customers' purchasing intentions before and after implementing this model approach in real SMEs business.

\section{REFERENCES}

Borgen SO. 2011. Product differentiation and cooperative governance. The Journal of Socio-Economics 40: 327-333. https://doi. org/10.1016/j.socec.2010.12.002.

Buchholz A, Wördemann W. 2001. What makes winning brands different: the hidden method behind the world's most successful brands. Journal of Euromarketing 10: 93-104. https:// doi.org/10.1300/J037v10n03_06.

Chang HH, Liu YM. 2009. The impact of brand equity on brand preference and purchase intentions in the service industries. The Service Industries Journal 29: 1687-1706. https://doi. org/10.1080/02642060902793557.

Erdogan BZ, Baker MJ. 2015. Towards a practitionerbased model of selecting celebrity endorsers. International Journal of Advertising 19: 2542. https://doi.org/10.1080/02650487.2000.11 104782.

Gani DS. 2004. Leadership in Indonesia: A Case for Managing. Leading in High Growth Asia: Managing relationship for teamwork and change, 195. https://doi. org/10.1142/9789812562135 0008.

Garretson JA, Clow KE. 1999. The influence of coupon face value on service quality expectations, risk perceptions and purchase intentions in the dental industry. Journal of Services Marketing 13(1):59-72.

Hair JF, Sarstedt M, Ringle CM, Mena JA. 2012. An assessment of the use of partial least squares structural equation modeling in marketing research. Journal of the academy of marketing science 40: 414-433. https://doi.org/10.1007/ s11747-011-0261-6.

Irawanto DW. 2009. An analysis of national culture and leadership practices in Indonesia. Journal of Diversity Management (JDM) 4: 41-48. https://doi.org/10.19030/jdm.v4i2.4957.

Kamins MA, Marks LJ. 1991. The perception of kosher as a third party certification claim in advertising for familiar and unfamiliar brands. Journal of the Academy of Marketing Science 19: 177185. https://doi.org/10.1007/BF02726494.

Kang J, Park-Poaps H. 2010. Hedonic and utilitarian shopping motivations of fashion leadership. Journal of Fashion Marketing and Management 14(2): 312-328. https://doi. org/10.1108/13612021011046138.

Kettani H. 2010 world muslim population. proceedings of the 8th Hawaii Internafional Conference on Arts and Humanifies, 2010: 12-16.

Lafferty BA, Goldsmith RE, Newell SJ. 2015. The Dual Credibility Model: The Influence of Corporate and Endorser Credibility on Attitudes and Purchase Intentions. Journal of Marketing 
Theory and Practice 10: 1-11. https://doi.org/1 0.1080/10696679.2002.11501916.

Liu MT, Brock JL. 2011. Selecting a female athlete endorser in China. European Journal of Marketing.

Marschall W. 1996. Leadership on Java. Gentle Hints, Authoritarian Rule. JSTOR.

Martensen A, Brockenhuus-Schack S, Zahid AL. 2018. How citizen influencers persuade their followers. Journal of Fashion Marketing and Management: An International Journal 22: 335-353. https://doi.org/10.1108/JFMM-092017-0095.

Mccracken G. 1989. Who Is the Celebrity Endorser? Cultural Foundations of the Endorsement Process. Journal of Consumer Research 16:310-321. https://doi.org/10.1086/209217.

Mcguire WJ. 1985. Attitudes and attitude change. The handbook of social psychology 233-346.

Money RB, Shimp TA, Sakano T. 2006. Celebrity endorsements in Japan and the United States: is negative information all that harmful? Journal of advertising research 46: 113-123. https:// doi.org/10.2501/S0021849906060120.

O'shaughnessy J, O'shaughnessy NJ. 2002. Marketing, the consumer society and hedonism. European Journal of Marketing.

Ohanian R. 1990. Construction and validation of a scale to measure celebrity endorsers' perceived expertise, trustworthiness, and attractiveness. Journal of advertising 19: 39-52. https://doi.or g/10.1080/00913367.1990.10673191.

Olsen SO. 2002. Comparative evaluation and the relationship between quality, satisfaction, and repurchase loyalty. Journal of the academy of marketing science 30: 240-249. https://doi. org/10.1177/0092070302303005.

Osei-Frimpong K, Donkor G, Owusu-Frimpong N. 2019. The Impact of Celebrity Endorsement on Consumer Purchase Intention: An Emerging Market Perspective. Journal of Marketing Theory and Practice 27: 103-121. https://doi. org/10.1080/10696679.2018.1534070.

Schouten AP, Janssen L, Verspaget M. 2019. Celebrity vs. Influencer endorsements in advertising: the role of identification, credibility, and Product-Endorser fit. International Journal of
Advertising 39: 258-281. https://doi.org/10.10 80/02650487.2019.1634898.

Spry A, Pappu R, Bettina CT. 2011. Celebrity endorsement, brand credibility and brand equity. European Journal of Marketing 45:882909.

Stanforth N. 1995. Fashion innovators, sensation seekers, and clothing individualists. Perceptual and Motor skills 81: 1203-1210.

Stogdill RM. 1948. Personal Factors Associated with Leadership: A Survey of the Literature. The Journal of Psychology 25: 35-71. https://doi.or $\mathrm{g} / 10.1080 / 00223980.1948 .9917362$.

Tahi HTT, Mckague K. 2011. Development of small and medium enterprises in a developing country. Journal of Enterprising Communities: People and Places in the Global Economy 5: 68-82. https://doi.org/10.1108/17506201111119626.

Tajfel H. 1972. Social categorization. Moscovici, S.(red.). Introduction à la psychologie sociale 30-37.

Wilson J, A J, Liu J. 2011. The challenges of Islamic branding: navigating emotions and halal. Journal of Islamic Marketing 2: 28-42. https:// doi.org/10.1108/17590831111115222.

Yoo B, Donthu N. 2001. Developing and validating a multidimensional consumer-based brand equity scale. Journal of business research 52: 1-14. https://doi.org/10.1016/S01482963(99)00098-3.

Belch GE, Belch MA. 2018. Advertising and Promotion: An Integrated Marketing Communications Perspective, McGraw-Hill Education.

Hofstede G. 2005. Organizations-Software of the Mind McGraw-Hill. NY.

Juran J, Godfrey AB. 1999. Quality handbook. Republished McGraw-Hill, 173.

Keller K. 2013. Strategic brand management: Global edition, Pearson Higher Ed.

Kotler P, Keller KL. 2016. Marketing management (15th global ed.). England: Pearson.

Malhotra NK, Birks DF, Nunan D. 2017. Marketing Research: An Applied Approach, Pearson. https://doi.org/10.4324/9781315088754.

Solomon MR. 2017. Consumer Behavior: Buying, Having, and Being. Harlow. Pearson Education. in Ergonomics Science 8: 1-35. 